\title{
Geographical variation in the composition and richness of forest snail faunas in northern Europe
}

\author{
B. M. Pokryszko ${ }^{1}$ and R. A. D. Cameron ${ }^{2}$ \\ ${ }^{1}$ Museum of Natural History, Wroclaw University, Sienkiewicza 21, 50-335 Wroclaw, Poland. \\ ${ }^{2}$ Department of Animal and Plant Sciences, University of Sheffield, Sheffield S10 2TN, UK, \\ and Department of Zoology, The Natural History Museum, London SW7 5BD, UK.
}

\begin{abstract}
The forest snail fauna of northern Europe originated from postglacial colonization from the south. While it is regionally poor (c. 150 species, excluding slugs), individual localities (clusters of sample sites within a few $\mathrm{km}$ of each other) can be rich by global standards (up to 57 species). Distance decay in faunal similarity is very gradual in lowland regions, but Carpathian faunas are sharply differentiated, and hold the most endemics. British faunas are remarkably uniform. Very little of this differentiation is due to congeneric replacement; it results mostly from shifts in the richness of whole families. Clausiliids in particular predominate in the Carpathians and adjacent areas, but this is not reflected in the apparent density of individuals: as species richness increases, average abundance of each declines. In general, small species are more widely distributed than large ones. Although the richest localities are found in the Carpathians, regional variation in local richness is slight. Substrate has significant effects: oligotrophic areas have poorer and more locally variable faunas. At a slightly larger scale, areas of less than 100 $\mathrm{km}^{2}$ holding more than 60 species can be found in many parts of the region (even more when slugs are included); the richest such patches hold about half the whole regional forest fauna. Comparison with limited data from regions further south shows that although they have much richer regional faunas, local communities are no richer than those of the north. Distance decay is much more rapid. These results are discussed, with global comparisons, in terms of the ways in which molluscan communities are assembled and structured.
\end{abstract}

Key words: Land snail faunas, N. Europe, species richness and composition

\section{INTRODUCTION}

At the largest scale, the pattern of land snail distribution in Europe is well known (Kerney, Cameron and Jungbluth, 1983; Falkner, Bank and von Proschwitz, 2001). There is an increase in species richness from north to south, and to a lesser extent from west to east (Cameron, 2004). These large-scale patterns have many causes. More southerly areas offer a wider range of habitats, each with its own fauna; they also hold more restricted endemics, the ranges of which reflect the distribution of glacial refugia during the Pleistocene. By contrast, large-scale variation in northern faunas reflects differential movement from refugia, sometimes over long distances, as well as ecological constraints (Hausdorf and Hennig, 2003). While arctic-alpine faunas survived the later phases of the Pleistocene in the north, moving northward or upward as the climate ameliorated, forest faunas in areas north of the major mountain ranges are composed of immigrants that have arrived from the south in the last 10,000 years.
This large-scale pattern does not persist at much smaller scales (Cameron, 2004). Within forests, local faunas (in areas of $1 \mathrm{~km}^{2}$ or less) do not show the same degree of latitudinal variation in richness. Some forest faunas north of the mountain ranges, for example on the Spitzberg, Tübingen (Schmid, 1966), in Bialowieża Forest (Cameron and Pokryszko, 2004), or in the Cotswolds (Cameron, Pokryszko and Long, in press), have levels of richness approaching those found in the famous subtropical sites in New Zealand studied by Solem and colleagues (Solem, 1984; Solem, Climo and Roscoe, 1981; see also comments in Emberton, 1995).

These issues of local relative to regional composition and richness have both theoretical (Srivastava, 1999), and conservation (Reid, 1998) significance. They also relate to Solem's (1984) analysis of global patterns in land mollusc diversity.

In an earlier paper (Cameron and Pokryszko, 2004), we noted the rather slow rate of distance decay in similarity in faunas (Nekola and White, 1999) on non-calcareous soils in the North European 
Plain. In this paper, we examine the pattern of variation in North European forest faunas as a whole, including those in mountainous areas and on limestone, where the richest faunas are to be found. We do this by comparing small areas of relatively uniform environments. We look at both richness and composition, and relate them both to Pleistocene/Holocene environmental changes, and to ecological constraints.

Although there is an extensive literature relating to local faunas in many European countries, variations in sampling methods and efficiency, and in the sizes and uniformity of the areas surveyed often make direct comparisons hazardous. We have therefore relied heavily on data collected by ourselves, using standard protocols, supplementing it with others where the sampling regime appears adequate, and where better geographical coverage was required. Although we discuss them briefly, we have excluded slugs from our formal analyses, as inspection of both our own data, and those of others, demonstrates that the sampling methods used are not adequate for them (Cameron, Pokryszko and Long, in press).

\section{SAMPLING METHODS, THE CHOICE OF STUDIES AND ANALYSIS}

Our own studies consist of clusters of samples made from $400 \mathrm{~m}^{2}$ plots within a few $\mathrm{km}$ of each other, and within forest; edges or ecotones being excluded (Cameron and Pokryszko, 2004). Within each plot, two people searched by eye for one hour, and 10 litres of litter was collected, and sieved and searched in the laboratory. All living and fresh specimens were identified and counted.

Our own studies are confined to southern England, to the south and east of Poland, and to the Ukrainian Carpathians. To increase the geographical coverage, we have included data from studies elsewhere in N. Europe (Table 1). In each case, it is possible to assemble a list of forest species resulting from sampling in more than one site, within a restricted district, using comparably effective sampling. We have excluded data relating to non-forest sites, and in the case of data from Körnig (1966), we have considered only the three sites in which the sampling regime appears to resemble our own. We have excluded species recorded as long dead shells only.

Analysis of between plot and other local variation in richness and composition will be presented elsewhere. For the purposes of analysis here, we have examined the composition of each cluster, combining all the plots involved. While biased sampling error (missing some species present) cannot be eliminated, we are satisfied that such errors are small when results from our plots are combined in this way (Cameron and Pokryszko,
2005). For some analyses, confined to our own data, we consider mean levels of recorded abundance per site.

Although all clusters are in forest, there is considerable ecological variation both within and between them. As Waldén (1981) has shown, in any one locality the richest single plots contain most of the species; poorer plots lose species, but do not, in general, gain others specialising in oligotrophic conditions. One exception to this occurs when some plots sampled include forested wetland (e.g. Cameron and Pokryszko, 2004). Thus we also consider the richest single plot within each cluster as an indication of syntopic richness, the $\alpha$ diversity of Whittaker (Southwood and Henderson, 2000). In some studies not made by us it is not possible to extract data for the richest single plot, and plot sizes vary (sometimes unspecified) between studies. We use the modified Whittaker's Index, $\mathrm{I}_{\text {max }^{\prime}}$ the ratio of the number of species recorded for the locality to the number in the richest plot as an indicator of the uniformity of the fauna (Koleff, Gaston and Lennon, 2003). The conventional index uses the mean number of species per plot (Southwood and Henderson, 2000) as the divisor; inspection of the data suggests that this will be influenced by the inclusion of poor individual plots, which differ merely in having a reduced fauna.

Faunal similarity has been compared in two ways:

1. Site by site comparison using the Nei index: $I_{N}=$ number of species in common/geometric mean of the species present at each site. This index is very similar to the familiar Jaccard index, but compensates in part for differences in the species richness at each site, and lacks the undesirable concave decay curve associated with single step changes in species held in common.

2. Site by site comparison using both presences and absences in relation to the whole array of 129 species, to estimate the significance of any associations, whether positive or negative (Cameron and Cook, 2001). The derived index gives the number of standard deviations separating the observed association and that expected by chance, given the number of species found at each site. Values in excess of 2.0 are formally significant.

\section{THE AREA COVERED AND THE SPECIES ARRAY}

Figure 1 shows the distribution of localities included in our analyses. All are north of the watershed formed by the Alps, the Böhmer Wald, the Sudetes and the Carpathians, except for the two localities (Ugol'ka and Kuziy) in the Ukrainian Carpathians. Within this area, also including the 


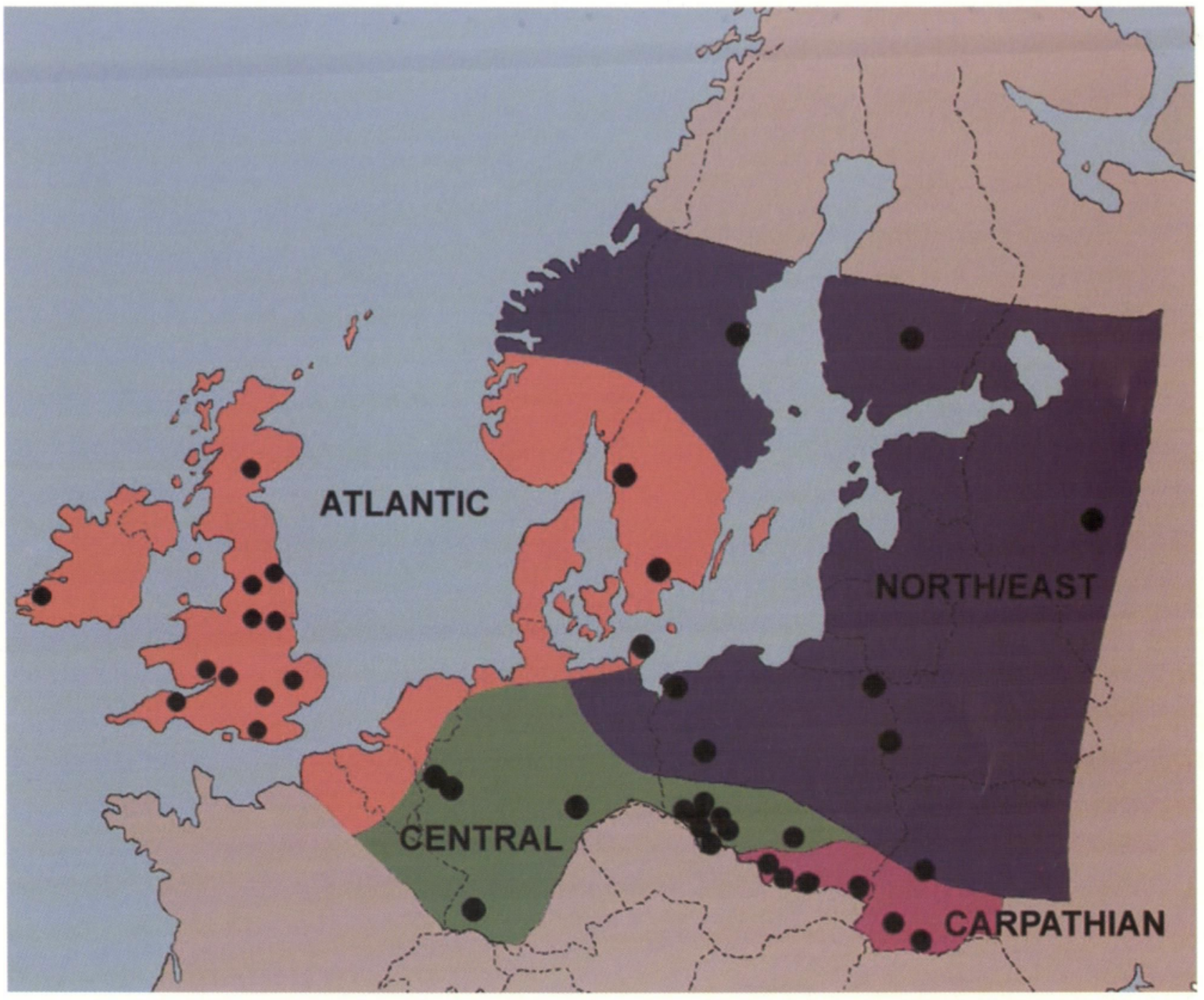

Figure 1 The position of localities used in this paper. Note that some spots include more than one locality.

northern half of France, there are c. 195 species of snail (slugs excluded), using the species identities, nomenclature and distributions given in Kerney, Cameron and Jungbluth (1983). There are two exceptions to the latter: included in the list for Kuziy (Ukraine) is Mastus bielzi (Kimakowicz, 1890), a species absent from the area covered by Kerney et. al. (1983) (Grossu, 1955), and in both Kuziy and Ugol'ka there is an unidentified Vestia species (Clausiliidae), clearly distinct from all other Vestia in the array.

Of these 195 species, 48 have open wetland, alpine or xerophile habitat preferences, and are unlikely to be found inside true forest. Of the 147 species remaining, the samples we consider contain $129(87 \%)$. Table 2 shows the missing species. Of the 18 involved, 13 are basically Alpine, 3 are extreme westerners, one is an anomalous endemic (W. Germany), and one extends from the Czech Republic to a single site in S.W. Poland. Overall, 10 species were recorded in one locality only, and 9 species in only two. Based on this, the Chao estimator (Southwood and Henderson, 2000) indicates that there might be $c .6$ species present but missed in our array. Our own samples contain 108 species, $73 \%$ of all forest species, and $84 \%$ of those included here. The array is thus reasonably representative of the fauna of the region as a whole.

\section{RESULTS}

Table 1 gives the details for each of the 46 localities we consider. A presence/absence table is available in electronic form from the authors.

\section{Faunal Similarities}

Figure 2 shows the dendrogram of affinities given by the Nei index. There is a manifest grouping of localities, which conforms to a geographical pattern. In order to examine general trends, four major regions are recognised, separated at the $50 \%$ affinity level: Atlantic, North and East, Central, and Carpathian. Within each, geographically coherent subregions can be distinguished (Figure 2). Mean 
Table 1 Details of the localities used. Ref. No. = locality numbers used in figure 1 and in the text. Long = degrees east of 10 degrees west. Subs = substrate: N, non-eutrophic; E, eutrophic; L, exposed limestone. No. of Sites = number of plots considered. Best plot $=$ greatest number of species recorded in a single plot. $I_{\max }=$ modified Whittaker's index (see text). $\mathrm{C} / \mathrm{P}=$ unpublished data of the authors. $\mathrm{M} / \mathrm{P}=$ unpublished data of $\mathrm{T}$. Maltz and B.M. Pokryszko. *Cameron and Pokryszko (2004), data from sources given in that paper. All species data exclude slugs.

\begin{tabular}{|c|c|c|c|c|c|c|c|c|c|c|}
\hline $\begin{array}{l}\text { Ref. } \\
\text { No. }\end{array}$ & Location & Country & Lat & Long* & Subs & $\begin{array}{l}\text { No. of } \\
\text { Sites }\end{array}$ & $\begin{array}{l}\text { No. of } \\
\text { species }\end{array}$ & $\begin{array}{l}\text { Best } \\
\text { Plot }\end{array}$ & $I_{\max }$ & Source \\
\hline 1 & South Bluffs & Sweden & 63.0 & 28.0 & E & 2 & 21 & 19 & 1.11 & Andersson (1961) \\
\hline 2 & Hyperite Hills & Finland & 62.1 & 35.5 & $\mathrm{E}$ & 21 & 23 & $\mathrm{n} / \mathrm{a}$ & $\mathrm{n} / \mathrm{a}$ & Valovirta (1968) \\
\hline 3 & Meadow woods & Sweden & 57.0 & 25.0 & $\mathrm{~N}$ & 24 & 30 & 21 & 1.43 & Wäreborn (1968) \\
\hline 4 & Talus slopes & Sweden & 57.9 & 22.0 & $\mathrm{E}$ & 6 & 43 & 34 & 1.26 & Waldén (1981) \\
\hline 5 & Cork woods & Ireland & 52.0 & 0.5 & $\mathrm{~N}$ & 11 & 29 & 20 & 1.45 & Bishop (1977) \\
\hline 6 & Perth woods & Scotland & 56.8 & 6.6 & $\mathrm{~N}$ & 5 & 30 & 25 & 1.20 & Waldén (unpublished) \\
\hline 7 & Perth woods & Scotland & 56.8 & 6.6 & $\mathrm{~L}$ & 4 & 30 & 26 & 1.15 & $\begin{array}{l}\text { Cameron and Greenwood } \\
\text { (1992) }\end{array}$ \\
\hline 8 & N. Yorks & England & 54.5 & 9.3 & E & 17 & 36 & 28 & 1.29 & Wardhaugh (1996) \\
\hline 9 & Malham & England & 54.1 & 7.8 & $\mathrm{~L}$ & 4 & 34 & 27 & 1.26 & Cameron (1978) \\
\hline 10 & Dark Peak & England & 53.3 & 8.2 & $\mathrm{~N}$ & 17 & 31 & 24 & 1.29 & Tattersfield (1990) \\
\hline 11 & White Peak & England & 53.3 & 8.2 & $\mathrm{~L}$ & 21 & 31 & 25 & 1.24 & Tattersfield (1990) \\
\hline 12 & Anston, S. Yorks & England & 53.4 & 8.8 & $\mathrm{~L}$ & 5 & 33 & 27 & 1.22 & Cameron (1999) \\
\hline 13 & Cambridge & England & 52.2 & 9.9 & E & 6 & 28 & 24 & 1.17 & Paul (1978) \\
\hline 14 & Wye Valley & England & 51.8 & 7.4 & $\mathrm{~L}$ & 7 & 35 & 28 & 1.25 & $\mathrm{C} / \mathrm{P}$ \\
\hline 15 & Cotswolds & England & 51.7 & 7.8 & $\mathrm{~L}$ & 8 & 40 & 35 & 1.14 & $\mathrm{C} / \mathrm{P}$ \\
\hline 16 & Chilterns & England & 51.7 & 9.1 & $\mathrm{~L}$ & 7 & 31 & 26 & 1.19 & $\mathrm{C} / \mathrm{P}$ \\
\hline 17 & South Downs & England & 50.9 & 9.1 & $\mathrm{~L}$ & 8 & 36 & 29 & 1.24 & $\mathrm{C} / \mathrm{P}$ \\
\hline 18 & Somerset & England & 51.2 & 6.7 & $\mathrm{E}$ & 6 & 33 & 22 & 1.50 & Bishop (1976) \\
\hline 19 & Rügen & Germany & 54.5 & 23.5 & E & 6 & 36 & 31 & 1.16 & Körnig (1980) \\
\hline 20 & Kottenforst, Bonn & Germany & 50.8 & 17.0 & $\mathrm{~N}$ & 12 & 28 & 20 & 1.40 & Bless (1977) \\
\hline 21 & Siebengeberg, Rhine & Germany & 50.8 & 17.0 & $\mathrm{E}$ & 18 & 35 & 28 & 1.25 & Hässlein (1961) \\
\hline 22 & Spitzberg, Tubingen & Germany & 48.5 & 19.0 & $\mathrm{~L}$ & $\mathrm{n} / \mathrm{a}$ & 36 & $\mathrm{n} / \mathrm{a}$ & $\mathrm{n} / \mathrm{a}$ & Schmid (1966) \\
\hline 23 & Hügellandes & Germany & 51.0 & 12.0 & $\mathrm{~L}$ & 3 & 36 & 34 & 1.06 & Körnig (1966) \\
\hline 24 & Kziąż & Poland & 50.8 & 26.3 & $\mathrm{E}$ & 5 & 48 & 36 & 1.33 & $M / P$ \\
\hline 25 & Góra Milek & Poland & 51.1 & 26.0 & $\mathrm{~L}$ & 4 & 38 & 29 & 1.31 & $\mathrm{C} / \mathrm{P}$ \\
\hline 26 & Wąwóz Myśliborski & Poland & 51.2 & 26.2 & $\mathrm{E}$ & 5 & 37 & 29 & 1.28 & $\mathrm{C} / \mathrm{P}$ \\
\hline 27 & Bardo & Poland & 50.6 & 26.6 & $\mathrm{E}$ & 5 & 42 & 25 & 1.68 & $\mathrm{C} / \mathrm{P}$ \\
\hline 28 & Mlynowiec & Poland & 50.4 & 26.8 & $\mathrm{~N}$ & 3 & 29 & 23 & 1.26 & $\mathrm{C} / \mathrm{P}$ \\
\hline 29 & Muszkowice & Poland & 50.7 & 27.1 & $\mathrm{~L}$ & 4 & 34 & 32 & 1.06 & $\mathrm{C} / \mathrm{P}$ \\
\hline 30 & Ojców & Poland & 50.2 & 29.6 & $\mathrm{~L}$ & 4 & 43 & 36 & 1.19 & C/P, Dzięczkowski (1972) \\
\hline 31 & Babia Góra & Poland & 49.6 & 29.4 & $\mathrm{E}$ & 3 & 35 & 35 & 1.00 & Dzięczkowski (1972) \\
\hline 32 & Tatra & Poland & 49.2 & 29.8 & $\mathrm{~L}$ & 4 & 38 & 35 & 1.09 & Dzięczkowski (1972) \\
\hline 33 & Pieniny & Poland & 49.3 & 30.4 & $\mathrm{~L}$ & 6 & 57 & 40 & 1.42 & $\begin{array}{l}\text { Dzięczkowski (1972), } \\
\text { Szybiak (2000) }\end{array}$ \\
\hline 34 & Pieniny & Poland & 49.3 & 30.4 & $\mathrm{~L}$ & 7 & 54 & 42 & 1.29 & $\mathrm{C} / \mathrm{P}$ \\
\hline 35 & Podlipowiec & Poland & 49.3 & 30.4 & $\mathrm{~N}$ & 8 & 48 & 30 & 1.60 & $\mathrm{C} / \mathrm{P}$ \\
\hline 36 & Bieszczady Mts & Poland & 49.2 & 32.4 & $\mathrm{E}$ & 10 & 50 & 38 & 1.32 & $\begin{array}{l}\text { Sulikowska-Drozd } \\
\text { (in press) }\end{array}$ \\
\hline 37 & W. Baltic coast & Poland & 54.0 & 25.0 & $\mathrm{~N}$ & 6 & 33 & 22 & 1.50 & $\begin{array}{l}\text { *Cameron and Pokryszko } \\
(2004)\end{array}$ \\
\hline 38 & Wielkopolski N. P. & Poland & 52.2 & 27.0 & $\mathrm{~N}$ & 6 & 34 & 24 & 1.42 & $\begin{array}{l}{ }^{*} \text { Cameron and Pokryszko } \\
(2004)\end{array}$ \\
\hline 39 & Białowieźa & Poland & 52.7 & 33.8 & E & 17 & 45 & 32 & 1.41 & $\begin{array}{l}\text { Cameron and Pokryszko } \\
(2004)\end{array}$ \\
\hline 40 & Hańcza & Poland & 54.3 & 32.8 & $\mathrm{~N}$ & 8 & 26 & 18 & 1.44 & $\mathrm{C} / \mathrm{P}$ \\
\hline 41 & L'viv & Ukraine & 49.8 & 34.0 & E & $\mathrm{n} / \mathrm{a}$ & 46 & $\mathrm{n} / \mathrm{a}$ & $\mathrm{n} / \mathrm{a}$ & Sverlova (2000) \\
\hline 42 & L'viv & Ukraine & 49.8 & 34.0 & $\mathrm{~N}$ & 3 & 27 & 17 & 1.59 & $\mathrm{C} / \mathrm{P}$ \\
\hline 43 & Kuziy & Ukraine & 48.1 & 34.1 & $\mathrm{~L}$ & 5 & 40 & 30 & 1.33 & $\mathrm{C} / \mathrm{P}$ \\
\hline 44 & Ugol'ka & Ukraine & 48.4 & 33.9 & $\mathrm{~L}$ & 7 & 38 & 27 & 1.41 & $\mathrm{C} / \mathrm{P}$ \\
\hline 45 & Valdai Hills & Russia & 57.5 & 43.0 & $\mathrm{E}$ & $\mathrm{n} / \mathrm{a}$ & 40 & $\mathrm{n} / \mathrm{a}$ & $\mathrm{n} / \mathrm{a}$ & Shikov (1981) \\
\hline 46 & Valdai Hills & Russia & 57.5 & 43.0 & $\mathrm{E}$ & $\mathrm{n} / \mathrm{a}$ & 45 & $\mathrm{n} / \mathrm{a}$ & $\mathrm{n} / \mathrm{a}$ & Shikov (1982) \\
\hline
\end{tabular}




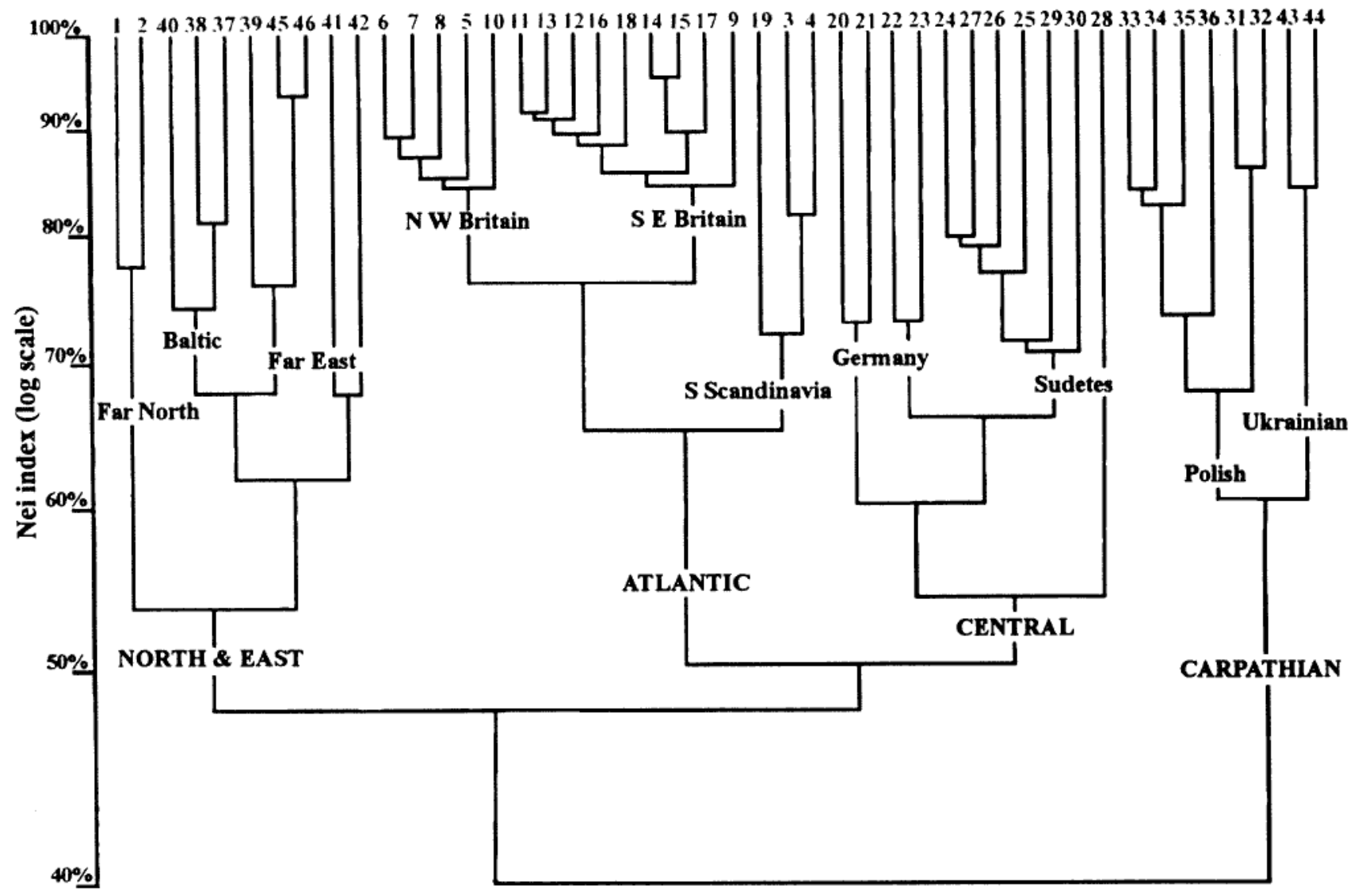

Figure 2 An UPGMA dendrogram of affinities between localities, using the Nei index (see text).

Table 2 Forest snails in N. Europe not found in the studies used here.

Acicula lineata
Acicula dupuyi
Orcula dolium
Pagodulina pagodula
Aegopinella ressmanni
Clausilia fimbriata
Charpentieria ornata
Pseudofusulus varians
Neostyriaca corynodes
Bulgarica vetusta
Elona quimperiana
Hygromia limbata
Trichia suberecta
Trichia graminicola
Trichia villosa
Chilostoma cingulatum
Cepaea sylvatica

similarities within each region are greater than those between them (Table 3).

Figure 3 shows the degrees of association given by the second index, with samples ordered, within the regions and subregions identified above, to maximise the amount of order in the array. The two indices are highly correlated $(\mathrm{r}=0.923)$. In both cases, it is apparent that the major axis of difference is between the British Isles at one extreme, and the
Rare N of Alps (Alpine)

France only: just into the N. half.

Rare $\mathrm{N}$ of Alps (Black Forest)

Alsace/Lorraine only $\mathrm{N}$ of Alps

S.E. Bavaria only

Alpine foreland of S. Germany only

Just gets into S. Poland

Alpine foreland, S. Germany

Alpine foreland, S. Germany

Isolated German relict pops only

Brittany endemic

Western France only (intro in UK)

Relict in S. Germany (Alpine)

One locality endemic, W. Germany

S. Germany only (Alpine)

Alpine: scattered relicts in S. Germany

Jura/Alpine: just into S.W. Germany.
Carpathians at the other. Negative, but nonsignificant, associations are recorded for many comparisons between these regions. The two other regions are intermediate.

The extent to which this axis explains variation can be seen by ordering the localities in terms of their affinities to the two most different (Figure 4). While the Carpathian and British Isles localities form distinct groups, the remainder are mixed. 


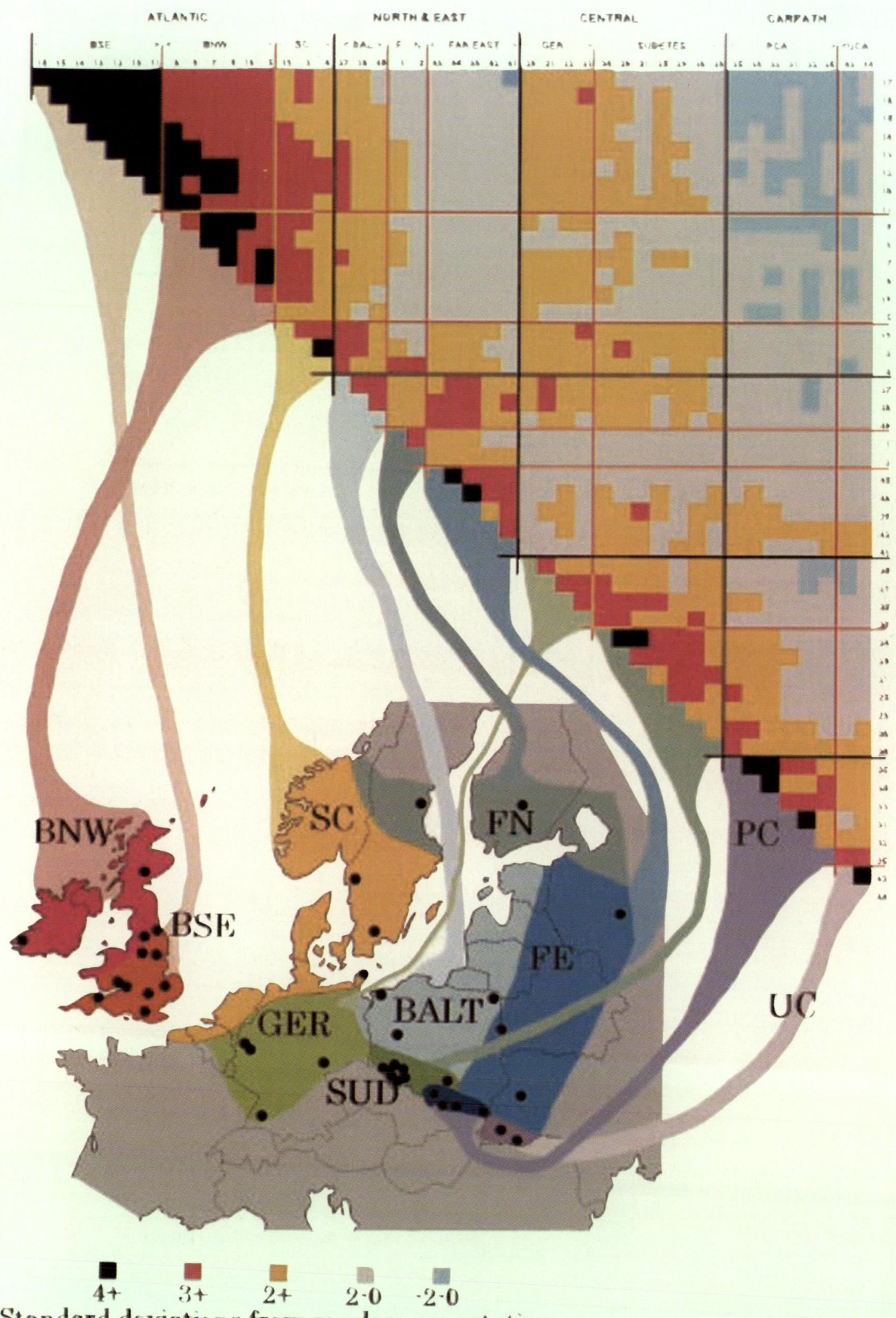

Standard deviations from random expectation

Figure 3 The matrix of associations given by the Cameron and Cook (2001) index in relation to subregions (see text). Localities are ordered among the subregions identified by the Nei index so as to give the greatest consistency in pattern. Values of the index are colour coded in the figure. Values of $>2$ ( + or - ) are formally significant at $\mathrm{P}<0.05$. No correction has been made for number of tests, as it is the pattern rather than the significance level that is relevant. Locality reference numbers are given across the top, and at the right. BNW = British Isles northwest; BSE = British Isles southeast; $\mathrm{SC}=$ Southern Scandinavia; GER = Germany; BALT = Baltic; FN $=$ Far north; FE = Far east SUD = Polish Sudetes; PC = Polish Carpathians; UC = Ukrainian Carpathians. 
Table 3 Mean values ( \pm Standard Errors) of the Nei index in locality-by-locality comparisons within and between the major groupings identified (see text).

\begin{tabular}{lllll}
\hline & Atlantic & Central & North/East & Carpathian \\
\hline Atlantic & $74.7 \pm 0.81$ & $50.6 \pm 0.48$ & $47.4 \pm 0.77$ & $31.8 \pm 0.51$ \\
Central & & $63.6 \pm 1.18$ & $47.8 \pm 0.88$ & $47.6 \pm 1.23$ \\
North/East & & & $62.7 \pm 1.59$ & $43.4 \pm 1.24$ \\
Carpathian & & & & $66.7 \pm 1.98$ \\
\hline
\end{tabular}

Table 4 Mean levels of similarity (Nei) amongst localities in the British Isles, and along the Carpathian Chain (see text).

\begin{tabular}{lllll} 
& $\begin{array}{l}\text { No. of } \\
\text { Localities }\end{array}$ & $\begin{array}{l}\text { Mean } \\
\text { Similarity }\end{array}$ & Variance & $\mathbf{F}_{\text {105, 91 }}$ \\
\hline British Isles & 14 & 79.4 & 54.8 & 2.54 \\
Carpathian Chain & 15 & 59.2 & 139.1 & $P<0.001$ \\
\hline
\end{tabular}

There are, however, distinct signs of geographical trends amongst them. Ojców (locality 30) for example, on limestone north of Kraków, connects the Carpathian and Sudetes faunas. The outlying position of the Far North sites (1 and 2) reflects, in part, their low species richness. There are clear eastwest trends in both Central and North and East regions. Apart from these broad geographical trends, it is evident that there are differences in the amount of variation within regions; although covering a much larger geographical area, faunas in the British Isles are much more uniform than those in the Carpathians, and, indeed, show greater affinity to faunas close to the Carpathians, than the latter do to the Carpathian faunas themselves. This relative uniformity in the lowlands is illustrated by the two isocline maps in Figure 5. A far larger area has faunas that have high affinity to that of western Ireland than those showing high affinities to the fauna of the Tatra.

This difference is emphasised by considering samples in the two areas for which we have the most, and the most reliable data, the British Isles and the whole Sudetes-Carpathian ridge. Both have samples extending over the same distance, c. 650 $\mathrm{km}$, north-south in the former, WNW to ESE in the latter. Table 4 shows that the Sudetes-Carpathian localities differ more amongst themselves, and also that the variance in degree of affinity is greater, indicating a geographical pattern within the region. Faunas in the Sudetes, c. $300 \mathrm{~km}$ from the main Carpathians, are as different from them as they are from the fauna in $W$. Ireland, c. 1,800 km away.

Despite the rather arbitrary nature of the two intermediate groups defined above, Central and North and East, shown clearly in Figure 4, we have retained them in many of the analyses that follow.

\section{Taxonomic Composition}

Of the 129 species considered here, eleven are universal, or nearly so, occurring in more than $80 \%$ of all localities, and in at least $50 \%$ of the localities in each major region considered separately (Table 5). With the exception of Cochlodina laminata, a clausiliid, they are all small litter-dwelling species. A further 20 species are also found in all four

Table 5 Universal species, occurring in $50 \%+$ of the localities in each region, and in $80 \%+$ of all localities (\% frequencies).

\begin{tabular}{lccccc}
\hline & Atlantic & Central & North/East & Carpathian & Total occurrences \\
\hline Euconulus fulous & 100 & 100 & 100 & 100 & 46 \\
Punctum pygmaeum & 94 & 100 & 100 & 100 & 45 \\
Carychium tridentatum & 100 & 100 & 80 & 100 & 44 \\
Acanthinula aculeata & 100 & 91 & 90 & 100 & 44 \\
Columella edentula & 94 & 91 & 100 & 87 & 43 \\
Aegopinella pura & 100 & 100 & 70 & 100 & 43 \\
Cochlicopa lubrica & 100 & 100 & 100 & 50 & 42 \\
Vitrina pellucida & 100 & 82 & 90 & 62 & 40 \\
Nesovitrea hammonis & 100 & 82 & 100 & 50 & 40 \\
Cochlodina laminata & 82 & 82 & 90 & 60 & 39 \\
Vitrea crystallina & 100 & 82 & 80 & 62 & \\
\hline
\end{tabular}




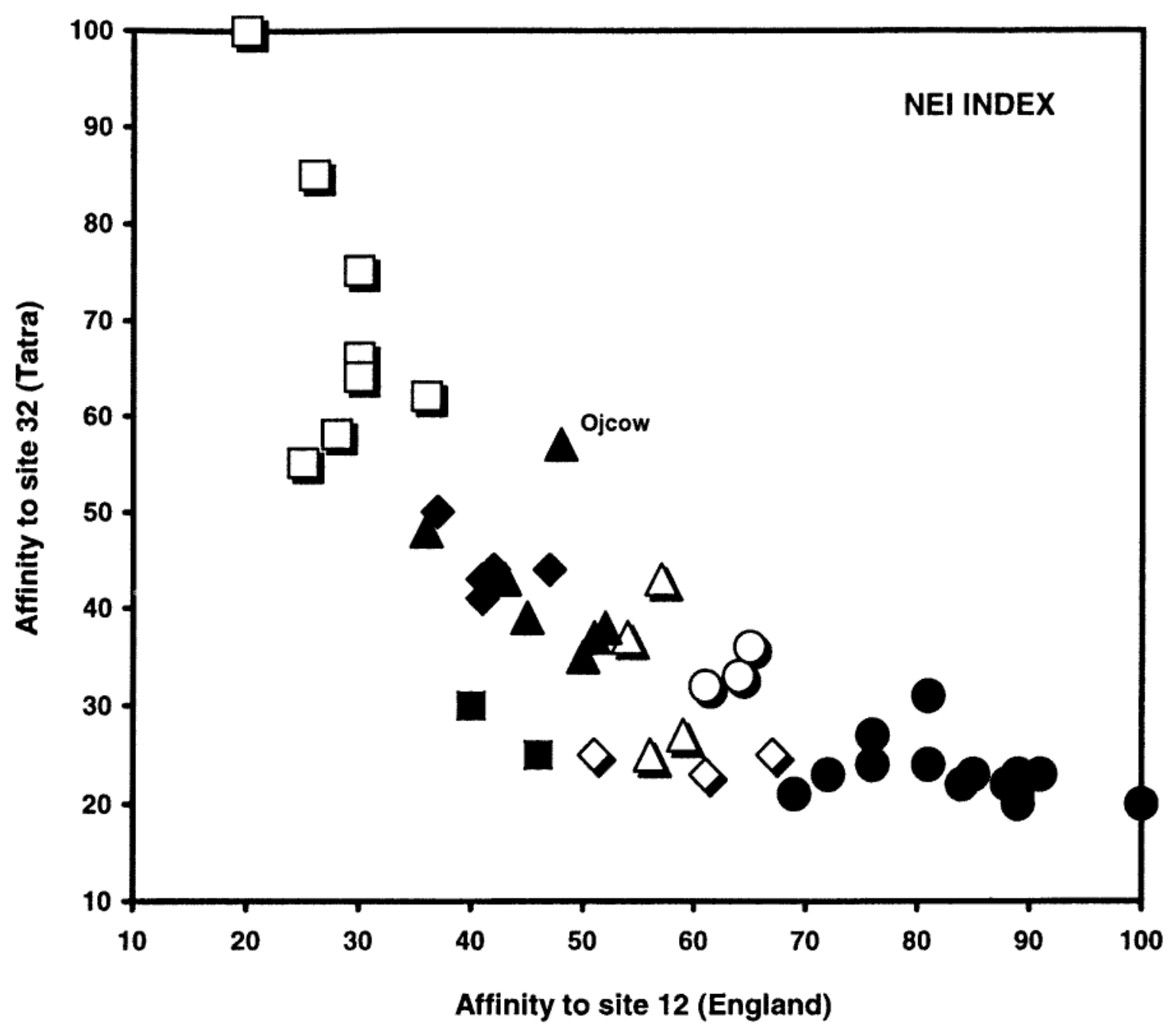

British Isles OS. Scandinavia $\Delta$ Germany $\Delta$ Sudetes $\diamond$ Baltic $\diamond$ Far East $\mathbf{m F a r}$ North $\square$ Carpathians

Figure 4 Localities ordered on their similarities (Nei index) to Locality 12 (Yorkshire, UK), and to Locality 32 (Tatra, Poland). These are the two most dissimilar localities (see text). Ojców (marked) lies between the Sudetes and the Carpathians proper.

regions, but at low frequencies in at least one. Of these, however, seven are missing from the British Isles localities within the Atlantic region.

At the other extreme, 27 species are recorded from three or fewer localities, and cannot, therefore, be present in all four regions. While most of these are native forest species that are rare or geographically restricted, a few are introduced species, or are not normally found under full forest cover. Despite the "noise" that such species may introduce, our analyses refer always to the full set of species recorded. The varying number of localities available in each subregion is an additional analytical constraint.

As expected, the distribution of species amongst the localities reflects what is known of their geographical distributions. Some are more restricted in our localities than their geographical range necessitates, but in general the fit is good. Thus, of the 72 species in the array not recorded in the British localities, only eight are known from Britain, though a further three are recorded in Holocene deposits (Kerney, 1999). When the subregions delimited in figures 2 and 3 are considered individually, 23 species are found in one only, while 7 are found in all ten. Of the 99 remaining species, only five show incoherent distributions in our localities, and in one of these, Vitrea subrimata, incoherence reflects a genuinely disjunct range (Kerney et al., 1983). While it is not surprising that the Far North (represented also by only two localities) is species-poor, this is also true of the Baltic relative to the neighbouring lowland subregions, Germany, S. Scandinavia and the Far East. The two Carpathian subregions hold far more unique species individually and combined than any other subregion or adjacent pair, followed by the British subregions combined, reflecting the pattern shown earlier. 


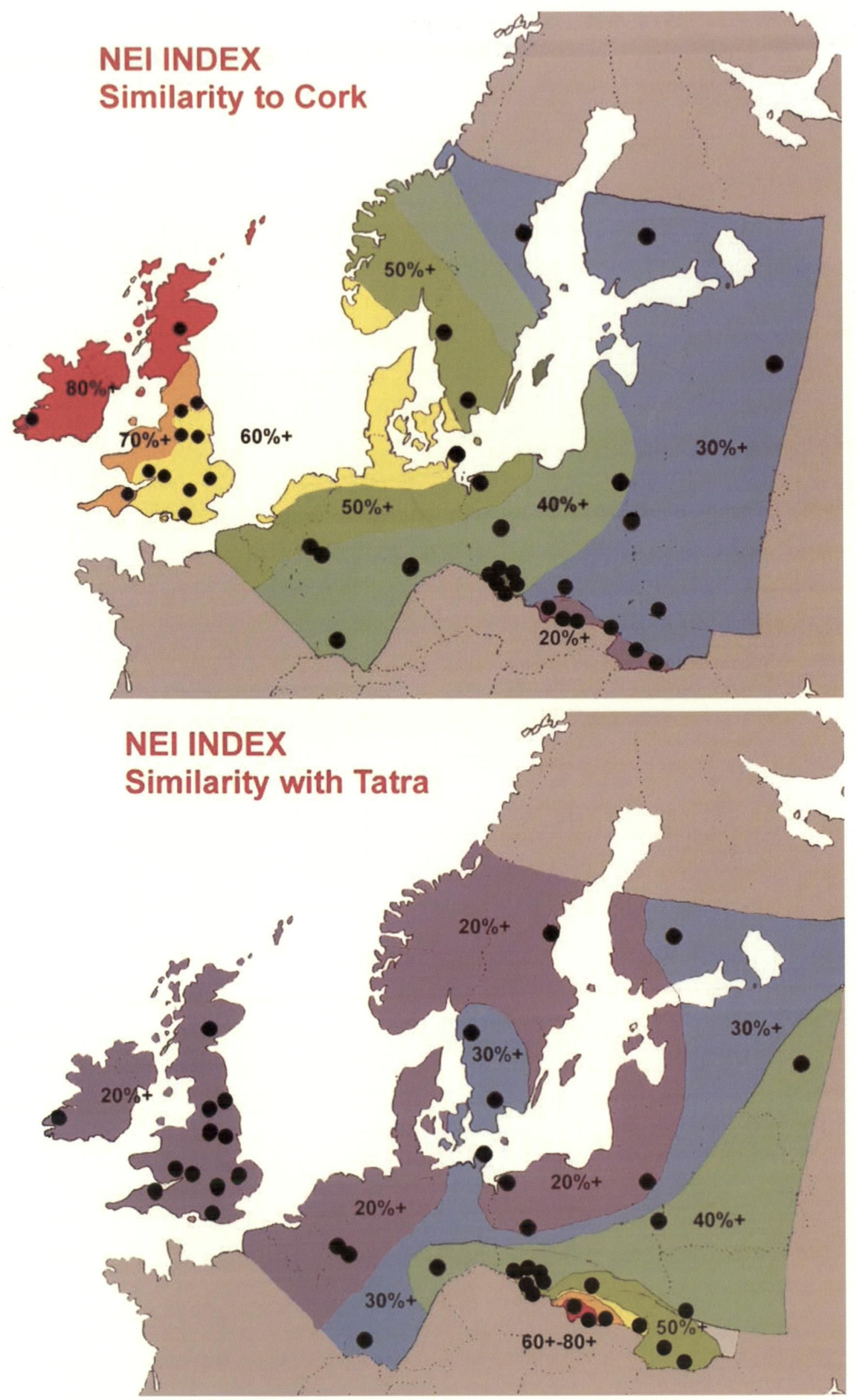

Figure 5 Isocline maps of Nei similarities to (a) Locality 5, Cork, Ireland, and (b) Locality 32, Tatra, Poland. 
Table 6 A. Unique species by Region, arranged in order of decreasing frequency of occurrence. Asterisks: for Atlantic, species not unique to British Isles, i.e. also/only in S. Scandinavia; for Central, species found only in the Polish Sudetes, i.e. in the Carpathian Chain. B. Species occurring in more than one region, but at least 2.5 times as frequent in the one labelled than in any other.

A

\begin{tabular}{|c|c|c|c|}
\hline Atlantic & Central & North/East & Carpathian \\
\hline $\begin{array}{l}\text { Lauria cylindracea* } \\
\text { Oxychilus helveticus } \\
\text { Perforatella subrufescens } \\
\text { Trichia striolata } \\
\text { Helix aspersa } \\
\text { Pomatias elegans } \\
\text { Acicula fusca } \\
\text { Spermodea lamellata* } \\
\text { Zonitoides excavatus } \\
\text { Euconulus alderi* } \\
\text { Leiostyla anglica } \\
\text { Monacha cantiana } \\
\text { Ashfordia granulata } \\
\text { Phenacolimax major } \\
\text { Vertigo angustior* }\end{array}$ & $\begin{array}{l}\text { Clausilia paroula } \\
\text { Eucobresia diaphana } \\
\text { Causa holosericum* } \\
\text { Sphyradium doliolum } \\
\text { Vitrinobrachium breve } \\
\text { Cochlodina costata* } \\
\text { Macrogastra lineolata }\end{array}$ & $\begin{array}{l}\text { Perforatella rubiginosa } \\
\text { Columella columella } \\
\text { Cochlicopa nitens }\end{array}$ & $\begin{array}{l}\text { Vitrea transsylvanica } \\
\text { Argna bielzi } \\
\text { Oxychilus orientalis } \\
\text { Semilimax kotulae } \\
\text { Vestia gulo } \\
\text { Vestia turgida } \\
\text { Vestia sp. } \\
\text { Balea fallax } \\
\text { Balea stabilis } \\
\text { Mastus bielzi } \\
\text { Trichia villosula } \\
\text { Trichia bielzi } \\
\text { Trichia lubomirskii } \\
\text { Trichia bakowskii } \\
\text { Drobacia banatica } \\
\text { Acicula perpusilla } \\
\text { Oxychilus inopinatus } \\
\text { Carpathica calophana }\end{array}$ \\
\hline
\end{tabular}

B

\begin{tabular}{llll}
\hline Atlantic & Central & North/East & Carpathian \\
\hline Azeca goodalli & Helicodonta obvoluta & Nesovitrea petronella & Aegopinella epipedostoma \\
Oxychilus alliarius & Balea biplicata & Vallonia pulchella & Oxychilus glaber \\
Vitrea contracta & & Vallonia costata & Vitrea subrimata \\
Cecilioides acicula & & Vertigo pygmaea & Eucobresia nivalis \\
Balea perversa & Vertigo ronnebyensis & Acicula parcelineata \\
Clausilia bidentata & Zoogenetes harpa & Discus perspectivus \\
& & Oxyloma elegans & Ruthenica filograna \\
& Zonitoides nitidus & Macrogastra tumida \\
& & Perforatella bidentata & Macrogastra latestriata \\
& Euomphalia strigella & Perforatella dibothrion \\
& & Perforatella umbrosa \\
& & & Trichia unidentata \\
& & & Faustina faustinum \\
\hline
\end{tabular}

Because some subregions contain very few localities, however, detailed analysis is restricted to the faunas of each major region, to get a better balance in the numbers of localities involved. 43 species are restricted to one region, and a further 31 are much more frequent in one region than in any others (Table 6). The species confined to, or predominant in, the Carpathians are mostly those with limited Carpathian or Alpine-Carpathian distributions. In the Atlantic region, however, while there are genuine western endemics such as $A$. fusca, L. anglica, A. granulata and $P$. subrufescens, there are also introduced species of southern origin, such as $H$. aspersa, M. cantiana and $O$. helveticus. Those in the Central region include species with Alpine or circum-Alpine centres of distribution, but in the North and East region only four of the 13 species shown in Table 6 are restricted to the far north or east, or have Arctic-Alpine ranges. The remainder are widespread, but not typical of forests elsewhere; six have wetland affinities, while the other three are often found in the open.

Species with restricted distributions are not randomly distributed with respect to the familylevel groups involved. Table 7 presents details of distribution overall, and for the four most speciose of such groups, which between them account for 86 species $(67 \%$ of the total). It also shows the distribution of species in relation to maximum shell dimension. The same figures are also given for the British Isles and the Carpathian Chain.

Disparities between regions are most evident in the case of the Clausiliidae, where the Carpathian region is richest, and has the most unique species. It 
Table 7 The distribution of numbers of species by region, overall, and in the British Isles and the Carpathian Chain, for the four largest family groups, and for species with maximum shell dimension above or below $5 \mathrm{~mm}$ (Vitrinidae excluded). Asterisked figures indicate the presence of known introductions: the helicoids Helix aspersa and Monacha cantiana in Britain, and the zonitids Oxychilus helveticus and O. draparnaudi, the former in Britain, the latter both in Britain and the Polish Sudetes.

\begin{tabular}{|c|c|c|c|c|c|c|c|}
\hline & Tot & Atl & Cent & $\mathbf{N} / \mathbf{E}$ & Carp & B.I. & C.Ch. \\
\hline No.of localities & 46 & 17 & 11 & 10 & 8 & 14 & 15 \\
\hline \multicolumn{8}{|l|}{ All Species } \\
\hline Species Present & 129 & $73^{*}$ & $79^{*}$ & 71 & 81 & 56 & 97 \\
\hline Unique species & 43 & $15^{*}$ & 7 & 3 & 18 & $10^{*}$ & 21 \\
\hline \multicolumn{8}{|l|}{ Clausiliidae } \\
\hline Present & 24 & 9 & 14 & 13 & 17 & 5 & 20 \\
\hline Unique & 8 & 0 & 3 & 0 & 5 & 0 & 6 \\
\hline Richest loc. & - & 8 & 8 & 11 & 16 & 4 & 16 \\
\hline Mean/loc. & - & 2.94 & 5.63 & 5.30 & 10.88 & 2.36 & 8.60 \\
\hline Standard Error & - & 0.42 & 0.41 & 1.22 & 0.95 & 0.22 & 0.84 \\
\hline \multicolumn{8}{|l|}{ Helicoidea } \\
\hline Present & $29^{*}$ & $15^{*}$ & 16 & 14 & 20 & 11 & 23 \\
\hline Unique & $12^{*}$ & $5^{*}$ & 1 & 1 & 5 & $5^{*}$ & 6 \\
\hline Richest loc. & - & 9 & 14 & 10 & 11 & 9 & 14 \\
\hline Mean/loc. & - & 6.53 & 8.90 & 4.90 & 8.00 & 6.57 & 8.73 \\
\hline Standard Error & - & 0.44 & 0.86 & 0.87 & 0.78 & 0.52 & 0.72 \\
\hline \multicolumn{8}{|l|}{ Zonitidae s.l. } \\
\hline Present & $24^{*}$ & $13^{*}$ & $17^{*}$ & 13 & 16 & $12^{*}$ & $20^{*}$ \\
\hline Unique & $6^{*}$ & 2 & 0 & 0 & 4 & $1^{*}$ & 4 \\
\hline Richest loc. & - & 10 & 12 & 10 & 12 & 10 & 12 \\
\hline Mean/loc. & - & 8.24 & 7.82 & 5.10 & 9.50 & 8.36 & 9.00 \\
\hline Standard Error & - & 0.18 & 0.62 & 0.72 & 0.60 & 0.20 & 0.51 \\
\hline \multicolumn{8}{|l|}{ Vertiginidae } \\
\hline Present & 9 & 8 & 4 & 7 & 4 & 4 & 4 \\
\hline Unique & 2 & 1 & 0 & 1 & 0 & 0 & 0 \\
\hline Richest loc. & - & 8 & 3 & 6 & 4 & 3 & 4 \\
\hline Mean/loc. & - & 2.65 & 2.10 & 4.2 & 2.75 & 2.00 & 2.67 \\
\hline Standard Error & - & 0.45 & 0.34 & 0.42 & 0.31 & 0.23 & 0.21 \\
\hline \multicolumn{8}{|l|}{ Less than $5 \mathrm{~mm}$} \\
\hline Present & 36 & 27 & 19 & 24 & 22 & 22 & 23 \\
\hline Unique & 11 & 6 & 1 & 1 & 3 & 2 & 3 \\
\hline \multicolumn{8}{|l|}{ More than $5 \mathrm{~mm}$} \\
\hline Present & 85 & 44 & 56 & 46 & 54 & 32 & 68 \\
\hline Unique & 28 & $8^{*}$ & 4 & 2 & 14 & $7^{*}$ & 17 \\
\hline
\end{tabular}

also has much the richest single locality, and the highest mean per locality. When examined in detail, it is apparent that both the Atlantic and North and East regions are geographically heterogeneous for this family: in the former, richness is concentrated in S. Scandinavia, and not in the British Isles, while in the latter, the Far Eastern localities are far richer than those in the Far North or in the Baltic.

A similar, though not so extreme, pattern can be seen in the Helicoidea, especially if the two introduced species restricted here to the British Isles are discounted. At the level of single localities, however, the Central region is the richest, due to some exceptional faunas in the Polish Sudetes.

By contrast, the Zonitidae show rather little regional variation in richness, and a low proportion of unique species. The same is broadly true at locality level. In the Vertiginidae, with many fewer species, a different pattern emerges: richness is greatest in the Atlantic and North and East regions. As with Clausiliidae, the Atlantic region is heterogeneous, with rich vertiginid faunas concentrated in S. Scandinavia. Overall, the number of vertiginid species increases northward (species on latitude: $\mathrm{r}=0.517, \mathrm{p}<0.001$ ).

Of these four groups, members of the Clausiliidae and Helicoidea are all relatively large; Vertiginidae are all very small, while Zonitidae span a wide range. The last two sections of Table 7 compare the distributions of species with shells more or less than $5 \mathrm{~mm}$ in maximum dimension, excluding Vitrinidae, for which this may not be a good measure (Hausdorf and Hennig, 2003). The ratio of large to small species present does not vary 
Table 8 Data on mean abundance per plot, and \% of all specimens for Clausiliidae and Helicoidea, and (\% only) for Punctum pygmaeum (P) and Vertiginidae in relation to the number of species involved. Subs = substrate as in table $1 ;$ No. $=$ number of species; Mean $=$ mean number of individuals per plot; $\%=\%$ of all individuals per locality; Mean $/ \mathrm{sp}=$ mean number of individuals per species present.

\begin{tabular}{|c|c|c|c|c|c|c|c|c|c|c|c|c|}
\hline \multirow[b]{2}{*}{ Locality } & \multicolumn{5}{|c|}{ Clausiliidae } & \multicolumn{4}{|c|}{ Helicoidea } & \multirow{2}{*}{$\begin{array}{l}\mathbf{P} \\
\%\end{array}$} & \multicolumn{2}{|c|}{ Vertiginidae } \\
\hline & Subs & No. & Mean & $\%$ & Mean/sp & No. & Mean & $\%$ & Mean/sp & & No. & $\%$ \\
\hline \multicolumn{13}{|l|}{ ENGLAND } \\
\hline Chilterns & $\mathrm{L}$ & 2 & 52.9 & 8.9 & 26.4 & 7 & 86.9 & 14.7 & 12.4 & 0.6 & 1 & 0.1 \\
\hline South Downs & $L$ & 3 & 86.0 & 11.8 & 28.7 & 9 & 44.0 & 6.1 & 4.9 & 0.4 & 1 & 0.02 \\
\hline Cotswolds & $\mathrm{L}$ & 3 & 73.1 & 10.4 & 24.4 & 9 & 63.5 & 9.1 & 7.1 & 2.9 & 1 & 0.03 \\
\hline Wye Valley & $\mathrm{L}$ & 3 & 67.3 & 10.9 & 22.4 & 8 & 34.6 & 5.6 & 4.3 & 2.2 & 1 & 0.1 \\
\hline Means & & 2.75 & 69.8 & 10.5 & 25.4 & 8.25 & 57.2 & 8.9 & 6.9 & 1.5 & 1 & 0.06 \\
\hline \multicolumn{13}{|l|}{ SUDETES } \\
\hline Góra Milek & $\mathrm{L}$ & 6 & 71.2 & 20.1 & 11.9 & 10 & 63.2 & 12.9 & 6.3 & 11.6 & 2 & 1.0 \\
\hline Muszkowice & $\mathrm{L}$ & 4 & 125.0 & 23.8 & 31.2 & 11 & 47.7 & 9.0 & 4.3 & 1.4 & 1 & 3.5 \\
\hline Ojców & $\mathrm{L}$ & 7 & 93.5 & 8.9 & 13.4 & 7 & 78.5 & 7.5 & 11.2 & 11.1 & 3 & 4.9 \\
\hline Myśliborski & $\mathrm{E}$ & 6 & 31.2 & 7.5 & 5.2 & 7 & 35.2 & 8.4 & 5.0 & 21.0 & 3 & 8.5 \\
\hline Bardo & $\mathrm{E}$ & 5 & 30.4 & 3.7 & 6.1 & 14 & 47.6 & 5.8 & 3.4 & 30.8 & 3 & 11.8 \\
\hline Mlynowiec & $\mathrm{N}$ & 6 & 41.0 & 11.5 & 6.8 & 4 & 14.3 & 4.0 & 3.6 & 14.2 & 3 & 15.0 \\
\hline Means & & 5.67 & 65.5 & 12.6 & 12.6 & 8.83 & 47.7 & 7.9 & 5.4 & 11.8 & 2.5 & 7.4 \\
\hline \multicolumn{13}{|c|}{ CARPATHIANS } \\
\hline Pieniny & $\mathrm{L}$ & 13 & 52.3 & 12.9 & 4.0 & 11 & 89.6 & 22.2 & 8.1 & 16.3 & 3 & 6.7 \\
\hline Ugol'ka & $\mathrm{L}$ & 8 & 50.7 & 22.7 & 6.3 & 6 & 45.0 & 20.2 & 7.5 & 4.4 & 3 & 0.7 \\
\hline Kuziy & $L$ & 8 & 38.6 & 9.42 & 4.8 & 8 & 49.2 & 12.0 & 6.2 & 4.9 & 3 & 0.7 \\
\hline Podlipowiec & $\mathrm{E}$ & 11 & 30.0 & 10.9 & 2.7 & 10 & 36.1 & 13.1 & 3.6 & 17.8 & 3 & 5.6 \\
\hline Means & & 10.0 & 42.9 & 14.0 & 4.3 & 8.75 & 55.0 & 16.9 & 6.3 & 10.3 & 3 & 3.4 \\
\hline \multicolumn{13}{|l|}{ EASTERN } \\
\hline Bialowieża & $\mathrm{E}$ & 11 & 33.5 & 12.1 & 3.1 & 8 & 24.6 & 9.0 & 3.1 & 9.7 & 4 & 4.7 \\
\hline L'viv & $\mathrm{N}$ & 5 & 32.7 & 18.9 & 6.5 & 5 & 37.7 & 21.8 & 7.5 & 0.2 & 3 & 11.2 \\
\hline
\end{tabular}

significantly between regions, although it is smallest in the Atlantic and North and East. It is significantly smaller in the British Isles relative to the Carpathian Chain $\left(\chi^{2}=3.8, p<0.05\right)$. In terms of unique species, three of the seven large species in the British Isles are introduced. If these are discounted, it is evident that the Carpathian Chain holds a higher proportion of large, unique species. In contrast, the Atlantic region holds the largest number of small species, and of small uniques; The British Isles hold virtually the same number of small species as the whole Carpathian Chain.

\section{Relative Abundance}

Data analysed above relate to presence and absence from localities. In the case of our own studies, a standardised sampling methodology, while not giving true density estimates, enables us to compare both the number of specimens of species collected per plot, and the percentage of all shells in a plot that belong to any species or higher taxon. While very crude, such figures enable us to look at changes in abundance between localities and regions.

Table 8 gives these data for selected groups of species from our own standardised studies. Amongst Clausiliidae, the pattern of species richness reflects the overall analysis above, but the recorded abundance of the Family, whether expressed as numbers per plot, or as a percentage of all shells, does not (for the relationship between percentage of all shells and number of species, $r^{2}=$ 0.0012). Although substrate clearly influences recorded abundance, and increases variance, mean abundance per species declines as richness increases. This relationship is shown in Figure 6; it is strong and highly significant $(\mathrm{P}<0.001)$.

By contrast, no clear trends can be seen amongst Helicoidea in terms of species richness, abundance, or percentage of the fauna, although the influence of substrate on recorded abundance is again visible. Data for Punctum pygmaeum and for the Vertiginidae show that both are much less abundant in the British Isles than in the overwhelming majority of the Polish and Ukrainian sites, even when the number of species of the latter is taken into account. Other universal species fluctuate without obvious geographical pattern, though substrate again affects recorded abundances.

\section{Species Richness and Hotspots}

Table 1 shows the number of species recorded at each locality, the number of species recorded in the richest plot (where the latter data are available), and some environmental data. The latter reflect the 


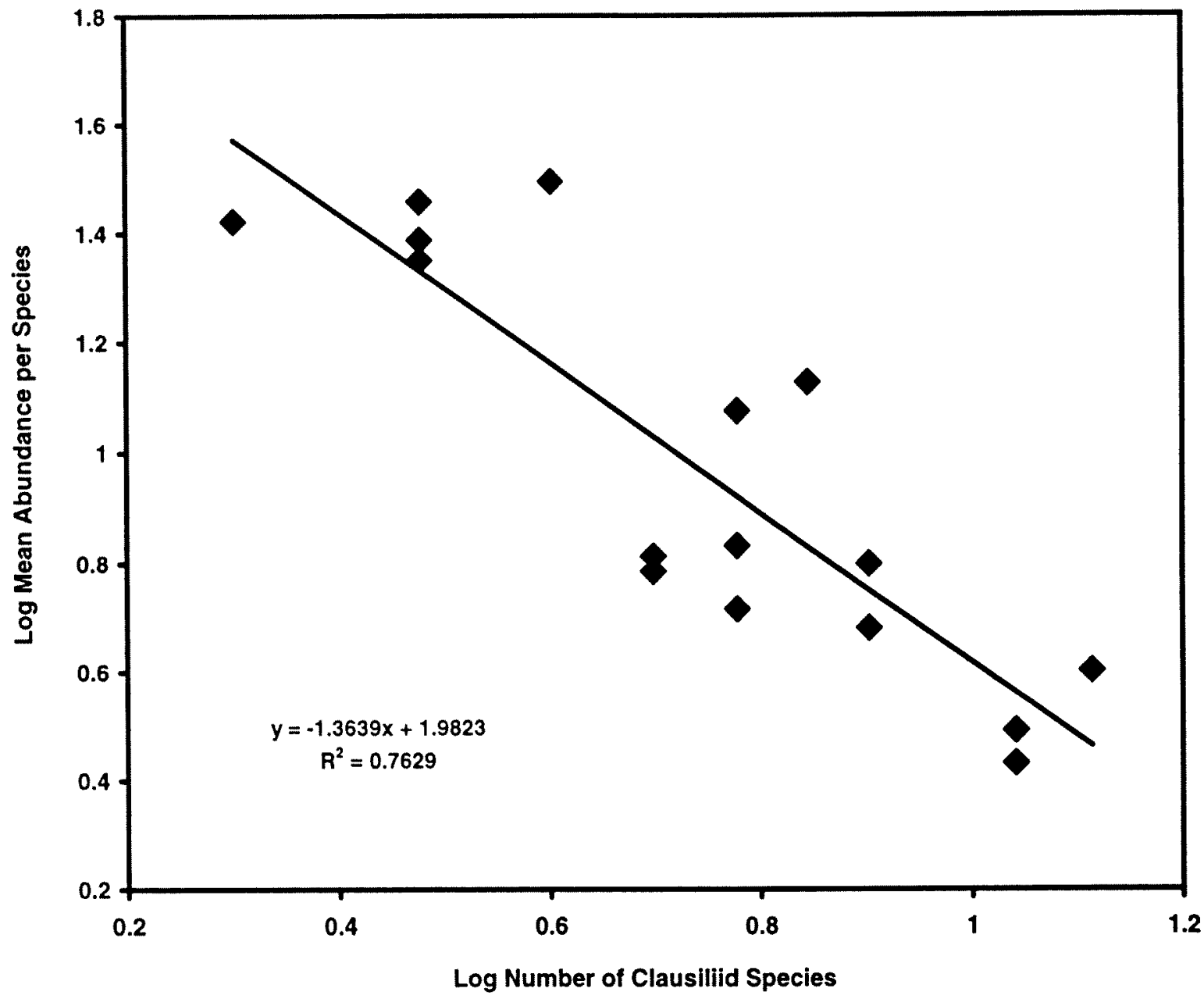

Figure 6 The logarithmic relationship between mean per plot abundance of individual clausiliid species and the number of clausiliid species in all localities sampled by the authors (Table 8 ).

general status of the forest types in each locality. Although there are formally significant relationships between species richness and both latitude (increase southwards) and longitude (increase eastwards), inspection of the data shows that the former is heavily influenced by the two, species-poor, localities in the Far North, and is not significant without them. The latter, though significant, accounts for only a small proportion of the total variance $\left(r^{2}=0.141\right)$.

The maximum locality richness is to be found in the Polish Carpathians east of the Tatra (L 33-36). Of other localities, only Ksiaż (L 24) in the Sudetes equals any of them. Of the three other localities that approach closely, L'viv (L 41) and Valdai (L 45) represent rather large areas, and both they and the third, Bialowieza (L 39) include wet alder forests, missing from all but locality 36 in the Polish Carpathian series. Except for the poor faunas in the extreme north (L 1 and 2), no other clear geographical pattern emerges.

Omitting the localities above, there are signs that the local environment influences richness. The mean number of species in non-eutrophic localities is $29.7 \pm 0.8$, significantly lower than that for eutrophic $(36.2 \pm 1.7)$, or for limestone $(35.7 \pm 0.9)$ localities. This effect is comparatively slight, reflecting the choice of the most favourable plots in non-eutrophic regions.

The pattern in the richest single plots is much the same. While the Carpathian group contains the richest plots, all other regions have individual plots with $32-36$ species (Table 1 ). The mean value of $I_{\max }$ is $1.295 \pm 0.024$; on average, the richest plot in a locality contains $77 \%$ of the species found. There is no consistent geographical variation in its value, nor does it vary with species richness $\left(r^{2}=0.022\right)$. As with richness, however, there is a relationship with substrate; the mean is higher in non-eutrophic localities than in eutrophic or limestone based ones (non-eutrophic, mean $1.41 \pm 0.04$, eutrophic mean $1.28 \pm 0.05$, limestone mean $1.22 \pm 0.03$ ). Plots vary more in composition within non-eutrophic localities than do those in richer places.

At both plot and at locality levels, therefore, the faunas of Polish Carpathian forests appear to be the richest in this particular array, although the difference between these faunas and some others is not great.

Where localities used in this study are close 
together, or we can add supplementary data from other, less precise studies, it is possible to consider the richness of forest faunas at a larger scale, c. 100 $\mathrm{km}^{2}$. In the Pieniny region of the Carpathians, we can add data from Urbański (1939) to those from localities 33-35 to give a total of 69 forest dwelling snail species, $53 \%$ of all the species in our array. In the two other areas of similar size for which we have such data, the totals are lower: 49 species each in Bialowieża (Cameron and Pokryszko, 2004), and the Cotswolds (Cameron, Pokryszko and Long, in press). Some areas of the Polish Sudetes and of southern Germany are probably comparable (Pokryszko and Cameron, unpublished; Schmid, 1966). The proportional differences seen here alter when slugs are also considered.

\section{Slugs}

Although slugs were found in all the studies used here, there are good reasons to think that their inventories are far less complete than for snails, and that they vary in completeness between localities. The evidence suggests that locality species richness is greatest in the west, and particularly in Britain. Thus, where we have data from several visits, some British localities have 13-16 species (Cameron, 1999 and unpublished; Long, unpublished; Wardhaugh, 1996). By comparison, the Bialowieża Forest has seven (Cameron and Pokryszko, 2004), and the Pieniny forests in the Carpathians eight. These differences, and the restricted geographical distribution of some Carpathian species (e.g. Bielzia coerulans) will increase the degree of geographical differentiation in faunal composition, and decrease the differences in locality species richness seen when only snails are considered. In particular, the greater number of slug species in the west tends to cancel out the trend for increased richness in the east.

\section{DISCUSSION}

\section{Coverage, Reliability and Human Influence}

The studies used here include the great majority of forest dwelling species recorded in the region. Nevertheless, it is significant that most of those missing have Alpine affinities; only one locality is near the Alpine foreland. From accounts available (e.g. Favre, 1927), it appears that forest faunas from below $1,000 \mathrm{~m}$ a.s.l. do not differ from their lowland counterparts as much as do those from the Carpathians.

It is inevitable that the results presented are subject to sampling error: species present will have been missed. The amalgamation of results from neighbouring plots, and the large sizes of the resulting samples should minimise this (Cameron and Pokryszko, 2005). Where the results of many previous general surveys are available, the locality lists presented here seem to contain the great majority of the available forest fauna. The greatest caution is required when considering oligotrophic localities, where sample sizes are generally smaller (Cameron and Pokryszko, 2004).

While all samples come from forests, there are, of course, ecological differences between them. In particular, some, but not all localities include riverine or floodplain forest; there is a considerable range of altitude involved, and there is a climatic gradient from oceanic in the west to continental in the east.

The whole of northern Europe has been subject to intensive human activity for thousands of years. We have carried out or chosen studies in areas retaining elements of natural forest vegetation, and the evidence from Quaternary studies is that, in general, faunas have survived in such areas (Evans, 1972; Wiktor, 1974; Alexandrowicz, 1997). Nevertheless, the influence of this activity is perceptible. In the west, and particularly in Britain, the principal effect in the context of our studies is the occurrence of introduced but naturalised species. More seriously, it seems likely that a combination of aerial pollution, grazing pressure and some climatic change has impoverished forest faunas in the Baltic subregion as used here (Cameron and Pokryszko, 2004); the absence or scarcity of clausiliids in many plots in this region is probably due to this.

In the context of the discussion that follows, it should be noted that all these factors tend to increase the degree of difference among localities. Since it is the relative uniformity in both composition and richness that characterises these faunas in comparison with others, they are unlikely to lead to false contrasts.

\section{Patterns and Processes}

The pattern of high local, but low regional species richness reported here reflects a very limited amount of geographical differentiation. At the extreme, within the British Isles, it is scarcely perceptible above the "noise" of sampling error, and involves only a few species. Over distances of $2,000 \mathrm{~km}$ or more, faunas away from the mountains retain Jaccard index similarities in the range $27-35 \%$ (Cameron and Pokryszko, 2004). Even along the Sudetes-Carpathian chain, it is much less than that recorded in many other parts of the world. Over this c. $650 \mathrm{~km}$ length, the mean Nei index is $59 \%$, equivalent to a Jaccard index of c. $40 \%$. Over shorter distances in the Aegean region, Jaccard is around 20-25\% (Cameron, Mylonas and Vardinoyannis, 2000), while over $610 \mathrm{~km}$ in Tanzanian coastal forests it is only $11 \%$ (Tattersfield, 1998). Similar rapid turnover occurs in the Kimberley region of Western Australia (Solem, 1985, 1988, 1991; Solem 
and McKenzie, 1991; Cameron, 1992)), and along the eastern seaboard of Australia (Stanisic, 1994; Moritz et al. 2001).

By contrast, faunas from the Great Lakes region of N. America show a pattern similar to that seen in N. Europe (Nekola and Smith, 1999; Nekola, 2003); Individual forest localities can hold a high proportion of the regionally available forest fauna. It seems clear that this pattern is related to the postglacial immigrant status of the forest fauna in both cases, as distinct from regions in which most of the fauna has survived in situ, albeit sometimes in scattered refugia.

The geographical variation seen in the $N$. European faunas is mainly at the level of higher taxa; rather little of it is caused by allopatric ranges of ecologically equivalent congeners (Hausdorf and Hennig, 2003). Thus, there are many more species of Arionidae in the west than in the east, of Vertiginidae in the north than in the south, and of Clausiliidae in the Carpathians and Far East than elsewhere. The extent to which this reflects familylevel adaptations to differing present climates, as opposed to being the product of varying composition amongst source faunas remains to be determined. Amongst Clausiliidae, our own studies suggest that the density or biomass of clausiliids is as high in British forests as it is in the Carpathians. In the latter, resources or niches are more finely partitioned simply because more species are available. By contrast, some widespread taxa (e.g. Punctum pygmaeum, some Vertigo species) show substantial differences in frequency and abundance between parts of the region, even though they occur throughout, suggesting ecological constraints. The existence of such constraints is also suggested by known range contractions since the mid-Holocene temperature maximum in N. Europe (Ložek, 1982, Kerney, 1999), though some of these may be a product of human disturbance.

This contrasts with some patterns elsewhere. In the Aegean (Mylonas et al., 2004), and in the Kimberley region of Western Australia (Solem 1988, 1991; Solem and McKenzie, 1991; Cameron, 1992), much of the difference between localities is accounted for by allopatric replacement by congeners: local "non-adaptive" radiations (Gittenberger, 1991). These tend to be concentrated amongst larger species with rather specific environmental requirements: Camaenidae in the Kimberley, Clausiliidae (Albinaria), Enidae (Mastus) and some Helicoidea in the Aegean. The case of Albinaria is particularly instructive: amongst at least 26 species present on Crete, individual localities (all of similar habitat) hold only one or two species. In the Carpathians, with a clausiliid fauna of c. 20 species, 16 were found in the richest locality, and 10 in the richest $400 \mathrm{~m}^{2}$ plot. Three species from the same genus often coexist.
Both the Aegean and the Kimberley are situated in areas where the effect of desiccation at intervals in the Pliocene and Pleistocene (coupled with tectonic and sea level changes in the Aegean) can be implicated in the fragmentation of ranges and consequent differentiation. In areas where climatic shifts have had less drastic effects, the patterns are rather different. Thus Solem, Climo and Roscoe (1981) for North Island New Zealand, and Stanisic (1994) for eastern Australian forests, attribute the high levels of both local and regional diversity to a gradual build up of sympatric diversity as a consequence of isolation by distance and subsequent back colonisation. In these cases, as in the very rich faunas of tropical rainforests reported in Cameroon (de Winter and Gittenberger, 1998) and in Borneo (Schilthuizen and Rutjes, 2001), there are many coexisting species in the same families and genera, and they are often small, litter-dwelling species such as Punctidae and Charopidae. In East Africa, both patterns coexist (Tattersfield, 1998). This is demonstrated elegantly in the case of Gulella species (Streptaxidae), where are often unique to particular forest localities, but such localities may hold many coexisting species. In the Kimberley, Solem (1985) has demonstrated some resource partitioning amongst coexisting camaenids; such work has started amongst Carpathian clausiliids (Sulikowska-Drozd, in press). In general, though, we have little information on possible interactions between closely related, but coexisting, species.

In terms of species richness, it is remarkable that these European forests, non-existent only 10,000 years ago, achieve levels of locality and plot richness not far short of those recorded in more stable regions with millions of years accumulation of diversity. Contra Solem (1984), this richness is genuinely syntopic, as reflected by low values of $\mathrm{I}_{\text {max }}$; indeed, individual square metre quadrats have been recorded with up to 35 species, including slugs (Schmid, 1966). Present habitats are manifestly favourable. In most cases, the locality faunas contain the overwhelming majority of the fauna known to occur in the vicinity. We are thus unable to say whether more species could be packed in if they were available locally. Further south in Europe, where regional diversity increases, it would appear that, even in forests of comparable character, locality species richness remains much the same (Table 9). In the case of the Czech Republic, we have an area that was also deforested in the full-glacial; faunas here are essentially part of the N. European assemblage. Further south, many new species are encountered, but richness is no higher.

There are further implications to this pattern. The uniformity of British faunas, not accompanied by any noticeable impoverishment at locality level, 
Table 9 Snail species richness in forest localities south of the study area. In the case of Flasar (1995) $\left(^{*}\right)$ it is hard to allocate the fauna as between a locality, or the equivalent of one of our plots (see text). Site $=$ richness of the best site/plot without obvious anthropogenic alteration. New $=$ number of species in the array considered not found in any studies used by us. Sites considered by Giusti et. al. (1985) are separated by more than $100 \mathrm{~km}$ (Ap = Apennines). Dashes indicate that the localities or plots are not directly comparable with the data from N. Europe.

\begin{tabular}{|c|c|c|c|c|}
\hline & Locality & Site & New & Source \\
\hline \multicolumn{5}{|l|}{ Czech Rep. } \\
\hline Moravia & $37^{*}$ & $*$ & 0 & Flasar, 1995 \\
\hline Bohemia & - & 28 & 1 & $\begin{array}{l}\text { Hlaváč and Horsák, } \\
2002\end{array}$ \\
\hline Bohemia & - & 34 & 1 & Hlaváč et. al. 2002 \\
\hline Bohemia & - & 30 & 1 & Flasar, 1971 \\
\hline \multicolumn{5}{|l|}{ Italy } \\
\hline Pre-alp to Ap & 48 & 24 & 23 & Giusti et. al., 1985 \\
\hline Novara & 42 & 22 & 8 & Bishop, 1980 \\
\hline \multicolumn{5}{|l|}{ Croatia } \\
\hline Medvednica & 39 & 21 & 15 & Štamol, 1991 \\
\hline Velika Kapela & a 36 & - & 18 & $\begin{array}{l}\text { Nikolic and Stamol, } \\
1990\end{array}$ \\
\hline
\end{tabular}

shows that many species, in disparate families, can disperse over large distances in a relatively short time. We may suspect that Carpathian faunas are richer in, for example, Clausiliidae, because distances from sources were shorter, and more species established simultaneously. Early arrivals might pre-empt niche space further north or west. Bearing in mind the short time span involved, we cannot be sure that the patterns we see are stable; changes (now grossly affected by human disturbance) may have been taking place as the initial influx of colonists interacted. Over similar time-spans, it seems that dispersal of species from refuges in the Kimberley, or in the Aegean, was hindered by encountering congeners. Hindrance might be due to conventional competition, or to the disadvantage of being a minority colonist amongst closely related but genetically unsuitable mating partners.

In this context, it is worth noting that many of the smallest litter dwelling species are capable of uniparental reproduction (Whitney, 1938; Morton, 1954; Baur, 1987 and 1989; Bulman, 1990; Pokryszko, 1990). Build up of congeneric sympatric diversity in low latitudes often involves such species. It also occurs in relatively oligotrophic localities, where low density and patchy distributions might allow a complex metapopulation structure to develop, permitting more coexistence than is possible in dense and continuous populations (Cameron et al., 2003). Given appropriate rates of speciation, migration and local extinction, such metapopulations can allow the coexistence of many ecologically identical species (Hubbell, 2001). Whatever the actual determinants of local diversity turn out to be, the N. European forest fauna shows us that when suitable habitats appear, they can be colonised in a geologically short time, over considerable distances, and to levels of local diversity which are high in a global context.

\section{ACKNOWLEDGEMENTS}

R.A.D.C.'s work in Poland was supported by a Royal Society short-term visit grant. We are grateful to David Long, Dr. Tomasz Maltz, Dr. Anna Sulikowska-Drozd and Henrik W. Waldén for permission to use unpublished data, to Dr. Laurence Cook for critical discussion and for computing the indices of similarity and producing matrices, and to Dr. Nina Sverlova for advice and guidance in Ukraine. Dr. Jeff Nekola reviewed an earlier version.

\section{REFERENCES}

Alexandrowicz, W.P. (1997). Malakofauna osadów czwartorzędowych i zmiany środowiska naturalnego Podhala $\mathrm{w}$ mlodszym wistulanie i holocenie. Folia Quaternaria 68: 7-132.

Andersson, J.S. (1961). The occurrence of some invertebrate animal groups in the South Bluffs in northern Sweden. Oikos 12: 126-156.

Baur, B. (1987). The minute land snail Punctum pygmaeum (Draparnaud) can reproduce in the absence of mate. Journal of Molluscan Studies 53: 112-113.

Baur, B. (1989). Growth and reproduction of the minute land snail Punctum pygmaeum (Draparnaud). Journal of Molluscan Studies 55: 383-387.

Bishop, M.J. (1976). The Mollusca in woodland around Nettlecombe Court, Somerset. Field Studies 4: 457-464.

Bishop, M.J. (1977). The Mollusca of acid woodland in west Cork and Kerry. Proceedings of the Royal Irish Academy B 77: 227-244.

Bishop, M.J. (1980). The Mollusca of acid woodland in the Italian province of Novara. Journal of Conchology 30: $181-188$.

Bless, R. (1977). Die Schneckenfauna des Kottenforstes bei Bonn (Mollusca: Gastropoda). Decheniana 130: 77100.

Bulman, K. (1990). Life history of Carychium tridentatum (Risso, 1826) (Gastropoda: Pulmonata: Ellobiidae) in the laboratory. Journal of Conchology 33: 321-333.

Cameron, R.A.D. (1978). Terrestrial snail faunas of the Malham area. Field Studies 4: 715-728.

Cameron, R.A.D. (1992). Land snail faunas of the Napier and Oscar Ranges, Western Australia: diversity, distribution and speciation. Biological Journal of the Linnean Society 45: 271-286.

Cameron, R.A.D. (1999). The slugs and snails of Anston Stones Wood. Sorby Record 35: 24-27.

Cameron, R.A.D. (2004). From continents to quadrats: species/area relationships in land mollusc faunas. Journal of Conchology, Special Publication 3: 39-54. 
Cameron, R.A.D. and Cook, L.M. (2001). Madeiran snails: faunal differentiation on a small island. Journal of Molluscan Studies 67: 257-267.

Cameron, R.A.D. and Greenwood, J.J.D. (1992). Some montane and forest faunas from eastern Scotland: effects of altitude, disturbance and isolation. In C. Meier-Brook (ed.), Proceedings of the Tenth International Malacological Congress, Tübingen, 1989. 437-442 Unitas Malacologica, Tübingen.

Cameron, R.A.D., Mylonas, M., Triantis, K., Parmakelis, A. and Vardinoyannis, K. (2003). Land snail diversity in a square kilometre of Cretan maquis: modest species richness, high density and local homogeneity. Journal of Molluscan Studies 69: 93-99.

Cameron, R.A.D., Mylonas, M. and Vardinoyannis, K. (2000). Local and regional diversity in some Aegean land snail faunas. Journal of Molluscan Studies 66: 131142.

Cameron, R.A.D. and Pokryszko, B.M. (2004). Land mollusc faunas of Bialowieża Forest (Poland), and the character and survival of forest faunas in the North European Plain. Journal of Molluscan Studies 70: 149164.

Cameron, R.A.D. and Pokryszko, B.M. (2005). Estimating the species richness and composition of land mollusc communities: problems, consequences and practical advice. Joturnal of Conchology 38: 529-547.

Cameron, R.A.D., Pokryszko, B.M. and Long, D.C. (in press). Snail faunas in Southern English calcareous woodlands, rich and uniform but geographically differentiated. Journal of Conchology

Dzięczkowski, A. (1972). Badania ilościowe slimaków buczyn poludniowo-zachodniej Polski. Studium ekologiczno-faunistyczne. [Quantitative researches of gastropods in the beech forests of south-western Poland. An ecology-faunistical study]. Prace Komisji Biologicznej PTPN 35: 1-89.

Emberton. K.C. (1995). Land snail community morphologies of the highest diversity sites of Madagascar, North America and New Zealand, with recommended alternatives to height-diameter plots. Malacologia 36: 43-66.

Evans, J.G. (1972). Land Snails in Archaeology. Seminar Press, London.

Falkner, G., Bank, R.A. and Von Proschwitz, T. (2001). Check-list of the non-marine molluscan species-group taxa of the states of northern, Atlantic and central Europe (CLECOM 1). Heldia 4 (1/2): 1-76.

Favre, J. (1927). Les mollusques post-glaciaires et actuels du bassin de Genève. Memoires du Société de Physique et d'Histoire Naturelle de Genève 40: 171-434.

Flasar, I. (1971). Zur Malakofauna des nordöstlichen Erzgebirges und des angrenzenden Gebirgsvorlands. Malakologische Abhandlungen Staatliches Museum für Tierkunde, Dresden 3: 135-170.

Flasar, I. (1995). Die Malakofauna des Waldes Doubrava, in Naturschuzgebiet Letovelskí Pomoraví. Malakologische Abhandlungen Staatliches Museum für Tierkunde, Dresden 17: 200-213.

Gittenberger, E. (1991). What about non-adaptive radiation? Biological Journal of the Linnean Society 43: 263-272.

Giusti, F., Castagnolo, L. and Manganelli, G. (1985). La fauna malacologica delle faggete italiane: breve cenni di ecologia, elenco delle specie e chiavi per il riconoscimento dei generi e delle entità più comuni. Bolletino Malacologico 21: 69-144.

Grossu, A. L. (1955). Fauna Republica Populare Romania 3(1) Mollusca, Gastropoda, Pulmonata. Bucharest.

Hässlein, L. (1961). Die Molluskenfauna des Siebengebirges und seiner Umgebung. Decheniana 9: $1-28$.

Hausdorf, B. and Hennig, C. (2003). Nestedness of northwest European land snail ranges as a consequence of differential immigration from Pleistocene glacial refuges. Oecologia 135: 102-109.

Hlaváč, J. C. and Horsák, M. (2002). Distribution of the snails Macrogastra badia and Laciniaria plicata (Gastropoda: Pulmonata: Clausiliidae) in the Bohemian Forest. Silva Gabreta 8: 191-204. (Czech with English summary).

Hlaváč, J C., Horsák, M., Beran, L., Dvorák, L., Juričová, L. and Vrabec, V. (2002). Molluscs of the Cesky Les Mts. 1: Selected localities in the northern part (Western Bohemia). Silva Gabreta 8: 205-228. (Czech with English summary)

Hubbell, S.P. (2001). The Unified Neutral Theory of Biodiversity and Biogeography. Princeton University Press, Princeton, NJ.

Kerney, M.P. (1999). Atlas of the Land and Freshwater Mollusca of Britain and Ireland. Harley Books, Colchester.

Kerney, M.P., Cameron, R.A.D. and Jungbluth, J.H. (1983). Die Landschnecken Nord-und Mitteleuropas. Paul Parey, Hamburg and Berlin.

Koleff, P., Gaston, K.J. and Lennon, J.J. (2003). Measuring beta diversity for presence-absence data. Journal of Animal Ecology 72: 367-382.

Körnig, G. (1966). Die Molluskengesellschaften des mitteldeutschen Hügellandes. Malakologische Abhandlungen Staatliches Museum für Tierkunde Dresden 1: 1-112.

Körnig, G. (1980). Molluskengesellschaften der Stubnitz (Rügen). Malakologische Abhandlungen, Staatliches Museum für Tierkunde Dresden 6: 229-239.

Ložek, V. (1982). Faunengeschichtliche Grundlinien zur spät- und nacheiszeitlichen Entwicklung der Molluskenbestände in Mitteleuropa. Rozpravy Československé Akademie Ved 92: 3-106.

Moritz, C., Richardson, K.S., Ferrier, S., Monteith, G.B., Stanisic, J. Williams, S.E. and Whiffin, T. (2001). Biogeographical concordance and efficiency of taxon indicators for establishing conservation priority in a tropical rainforest biota. Proceedings of the Royal Society of London B 268: 1875-1881.

Morton, J.E. (1954). Notes on the ecology and annual cycle of Carychium tridentatum at Box Hill. Proceedings of the Malacological Society of London 31: 30-46.

Mylonas, M., Giokas, S., Parmakelis, A., Triantis, K. and Vardinoyannis, K. (2004). Evolution and diversity of land snails in a laboratory of nature: the Aegean archipelagos. World Congress of Malacology, Perth, Western Australia. Molluscan Megadiversity: Sea, Land and Freshwater. Abstracts: 103.

Nekola, J.C. (2003). Large scale terrestrial gastropod community composition patterns in the Great Lakes 
region of North America. Diversity and Distributions 9: 55-71.

Nekola, J.C. and White, P.S. (1999). Distance decay of similarity in biogeography and ecology. Journal of Biogeography 26: 867-878.

Nekola, J.C. and Smith, T. (1999). Terrestrial gastropod richness patterns in Wisconsin carbonate cliff communities. Malacologia 41: 253-269.

Nikolic, T. and Štamol, V. (1990). Coenological investigations of snails (Mollusca: Gastropoda) in some phytocoenoses of the Bijele Stijena (Vilka Kapela, Hrvatska, Jugoslavija). Biološki Vestnik 38: 2936.

Paul, C.R.C. (1978). The ecology of Mollusca in ancient woodland. 3. Frequency of occurrence in west Cambridgeshire woods. Journal of Conchology 29: 295300.

Pokryszko, B.M. (1990). Life history and population dynamics of Vertigo pusilla O. F. Müller, 1774 (Gastropoda: Pulmonata: Vertiginidae), with some notes on shell and genital variability. Annales Zoologici 43: $407-432$

Reid, W.V. (1998). Biodiversity hotspots. Trends in Ecology and Evolution 13: 275-280.

Schilthuizen, M. and Rutjes, H.A. (2001). Land-snail diversity in a square kilometre of tropical rainforest in Sabah, Malaysian Borneo. Journal of Molluscan Studies 67: 417-423.

Schmid, G. (1966). Die Mollusken des Spitzbergs. Natur und Landschaftsschutzgebiete, Baden Württemburg 3: 596-701.

Shikov, E.V. (1981). Mollyuski khvoynykh lesov Valdayskoy Vozvyshennosti i sopredelnykh territoryi. Fauna Verkhnevolzha i yeyo okhrana i ispolzovanye. In V.I. Zinovev, M.G. Sorokin and K.E. Tomashevskiy (eds), Fauna Verkhnevolzha $i$ yeyo Okhrana $i$ Ispolzovanye, 28-46. Kalininskyi Gosudarstvennyi Universitet, Kalinin. (in Russian).

Shikov, E.V. (1982). Fauna nazemnykh mollyuskov prirodnikh i antropogennykh landshaftov Valdayskoy Vozvyshennosti i sopredelnykh territoryi. In V.I. Zinovev, M.G. Sorokin and K.E. Tomashevskiy (eds), Zhivotnyi Mir Centra Lesnoy Zony Evropsyskoy Chasti SSSR, 138-183. Kalininskyi Gosudarstvennyi Universitet, Kalinin. (in Russian).

Solem, A. (1984). A world model of land snail diversity and abundance. In Solem, A. and van Bruggen A.C. (eds), World-wide Snails, 6-22. E.J. Brill/W. Backhuys, Leiden.

Solem, A. (1985). Simultaneous character convergence and divergence in Western Australian land snails. Biological Journal of the Linnean Society 24: 143-163.

Solem, A. (1988). Maximum in the minimum: biogeography of land snails from the Ningbing Ranges and Jeremiah Hills, northeast Kimberley, Western Australia. Journal of the Malacological Society of Australia 9: 59-113.

Solem, A. (1991) Land snails of Kimberley rainforest patches and biogeography of all Kimberley land snails. In McKenzie, N.L., Johnston, R.B. and Kendrick, P.G. (eds), Kimberley Rainforests, 145-246. Surrey Beatty and Sons, Pty Limited, Chipping Norton.

Solem, A., Climo, F.M. and Roscoe, D.J. (1981). Sympatric species diversity of New Zealand land snails. New Zealand Journal of Zoology 8: 453-485.
Solem, A. and McKenzie, N.L. (1991). The composition of land snail assemblages in Kimberley rainforests. In McKenzie, N.L., Johnston, R.B. and Kendrick, P.G. (eds), Kimberley Rainforests, 247-265. Surrey Beatty and Sons, Pty Limited, Chipping Norton.

Southwood, T.R.E. and Henderson, P.A. (2000). Ecological Methods. Blackwell, Oxford.

Srivastava, D.S. (1999). Using local-regional richness plots to test for species saturation: pitfalls and potentials. Journal of Animal Ecology 68: 1-16.

Stamol, V. (1991). Coenological study of snails (Mollusca: Gastropoda) in forest phytocoenoses of Medvednica mountain (NW Croatia, Yugoslavia). Vegetatio 95: 3354.

Stanisic, J. (1994). The distribution and patterns of species diversity of land snails in eastern Australia. Memoirs of the Queensland Museum 36: 207-214.

Sulikowska-Drozd A. (in press). Distribution and habitat preferences of clausiliids (Gastropoda: Pulmonata: Clausiliidae) in the eastern part of the Polish Carpathians. Folia Malacologica.

Sverlova, N. (2000). Zur städtischen Landschneckenfauna der Ukraine (Gastropoda: Pulmonata). Malakologische Abhandlungen Staatliches Museum für Tierkunde Dresden 20: $112-117$.

Szybiak, K. (2000). Malacocenoses of the valley of the stream Pieniński Potok, Pieniny National Park. Folia Malacologica 8: 249-256.

Tattersfield, P. (1990). Terrestrial mollusc faunas from some south Pennine woodlands. Journal of Conchology 33: 355-374.

Tattersfield, P. (1998). Patterns of diversity and endemism in East African land snails, and the implications for conservation. Journal of Conchology, Special Publication 2: 77-86.

Urbański, J. (1939). Mięczaki Pienin ze szczególnym uwzględnieniem terenu polskiej częsci Parku Narodowego. Prace Komisji MatematycznoPrzyrodniczej PTPN Poznań 9: 263-505.

Valovirta, I. (1968) Land molluscs in relation to acidity on hyperite hills in Central Finland. Annales Zoologici Fennici 5: 245-253.

Waldén, H.W. (1981). Communities and diversity of land molluscs in Scandinavian woodlands. I. High diversity communities in taluses and boulder slopes in SW Sweden. Journal of Conchology 30: 351-372.

Wardhaugh, A.A. (1996). The terrestrial molluscan faunas of some woodlands in north-east Yorkshire, England. Journal of Conchology 35: 313-328.

Wäreborn, I. (1969). Land molluscs and their environments in an oligotrophic area in southern Sweden. Oikos 20: 461-479.

Whitney, M. (1938). Some observations on the reproductive cycle of common land snail, Vallonia pulchella. Influence of environmental factors. Proceedings of the Indiana Academy of Sciences 47: 299307.

Wiktor, A. (1974). Fauna mięczaków subfosylnych rezerwatu Muszkowicki Las Bukowy $w$ powiecie Ząbkowickim. Ochrona Przyrody 40: 269-290.

de Winter, A.J. and Gittenberger, E. (1998). The land snail fauna of a square kilometre patch of rainforest in southwestern Cameroon: high species richness, low abundance and seasonal fluctuations. Malacologia 40: 231-250. 